\title{
ELMSTREET (Esophageal Lesions during MitraClip uSing TRansEsophageal Echocardiography Trial)
}

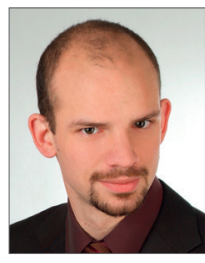

Tobias F. Ruf ${ }^{1 *}$, MD; Felix M. Heidrich ${ }^{1}$, MD; Krunoslav M. Sveric ${ }^{1}$, MD;

Christian Pfluecke', MD; Anna-Magdalena Stephan², MD; Ruth H. Strasser ${ }^{1}$, MD;

Stephan Wiedemann ${ }^{1}, \mathrm{MD}$

1. Department of Medicine and Cardiology, Technische Universität Dresden, Heart Cêntre Dresden, University Hospital Dresden, Dresden, Germany; 2. Medical Department I, Technische Universität Dresden, University Hospital Dresden, Dresden, Germany

T.F. Ruf and F.M. Heidrich contributed equally to this manuscript.

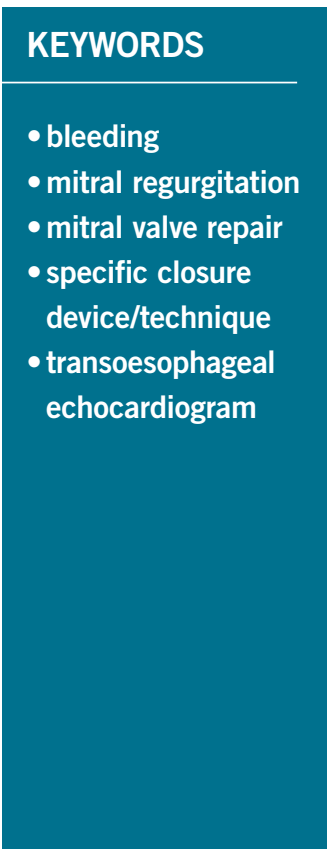

\section{Abstract}

Aims: We aimed to evaluate possible detrimental effects of transoesophageal echocardiography (TEE) on the oesophageal tissue during percutaneous mitral valve repair (PMVR).

Methods and results: From March 2014 to July 2015, 186 patients were treated for severe mitral regurgitation with PMVR using the MitraClip system. In 40 patients, oesophago-gastro-duodenoscopy was performed due to symptoms related to the gastrointestinal tract. Based on the procedure duration, patients were classified into group 1 ( $>60$ minutes, $n=23$ ) or into group $2(<60$ minutes, $n=17)$, respectively. Oesophageal lesions (OL) were found in 19 patients (group 1: $\mathrm{n}=17$ vs. group 2 : $\mathrm{n}=2, \mathrm{p}<0.0001$ ). We observed a change in leucocyte count after the procedure (group 1: $+2.00 \mathrm{Gpt} / \mathrm{L}[\mathrm{SEM} \pm 0.48]$ vs. group 2: $+0.54 \mathrm{Gpt} / \mathrm{L}$ [SEM \pm 0.36$], \mathrm{p}=0.028)$. This change was more apparent when comparing patients with OL vs. those without (lesions: $+2.65 \mathrm{Gpt} / \mathrm{L}[\mathrm{SEM} \pm 0.56]$ vs. no lesions: $+0.23 \mathrm{Gpt} / \mathrm{L}[\mathrm{SEM} \pm 0.12], \mathrm{p}<0.0001$ ).

Conclusions: Prolonged use of TEE during PMVR with a procedure time of longer than 60 minutes increases the risk of oesophageal damage. An exceptional rise of leucocyte count after PMVR may raise suspicion of new oesophageal damage.

*Corresponding author: Zentrum für Kardiologie - Kardiologie I, Johannes Gutenberg-Universität Mainz, Langenbeckstraße 1, 55131 Mainz, Germany. E-mail: tobias.ruf@unimedizin-mainz.de 


\section{Abbreviations}

$\begin{array}{ll}\text { ASD } & \text { atrial septal defect } \\ \text { EGD } & \text { oesophago-gastro-duodenoscopy } \\ \text { OL } & \text { oesophageal lesions } \\ \text { LVEF } & \text { left ventricular ejection fraction } \\ \text { MC } & \text { MitraClip } \\ \text { MR } & \text { mitral regurgitation } \\ \text { PMVR } & \text { percutaneous mitral valve repair } \\ \text { ROC } & \text { receiver operating characteristic } \\ \text { TEE } & \text { transoesophageal echocardiography } \\ \text { TIA } & \text { transient ischaemic attacks } \\ \text { TTE } & \text { transthoracic echocardiography }\end{array}$

\section{Introduction}

Mitral valve regurgitation (MR) is the second most common valve disease after aortic stenosis requiring surgery ${ }^{1}$. In patients who are not found eligible for surgery, percutaneous mitral valve repair (PMVR), using the MitraClip ${ }^{\circledR}$ system (Abbott Vascular, Santa Clara, CA, USA), has become an alternative treatment ${ }^{2-5}$, achieving improvements in LVEF, functional capacity and quality of life $\mathrm{e}^{6-8}$. When compared to a conservative approach in treating MR, PMVR increases survival ${ }^{2}$. Although the incidences of mortality and morbidity are $l_{0}{ }^{4}$, major complications exist, the foremost being bleeding at the puncture site. Also, structural damage, such as persistence of an atrial septal defect (ASD) and neurological deficits, i.e., transient ischaemic attacks (TIA) or strokes, occur ${ }^{4,9}$.

To guide clip positioning, transoesophageal echocardiography (TEE) is required ${ }^{10-12}$. TEE use has been associated with damage to the oesophagus, especially when applying high pressure over a long period $^{13,14}$. A potential risk can be assumed from using TEE during PMVR, especially as the procedure time of PMVR has been described as ranging from 20 to up to 390 minutes $^{2,5,15}$. The aim of this prospective registry study is to investigate the possible role of TEE as a cause for damage to the oesophagus occurring during PMVR.

\section{Material and methods STUDY POPULATION}

We investigated the data of the prospective Dresdner MitraClip registry from March 2014 until July 2015. All patients included were treated for symptomatic MR grades $2+$ with PMVR. The patients were not eligible for cardiac surgery, as assessed by the Heart Team, while clip implantation was technically feasible.

Patients were excluded if no oesophago-gastro-duodenoscopy (EGD) was performed. EGD was ordered at the treating physician's discretion. Patients were allocated into groups, depending on procedure duration (group 1: $>60$ minutes, $n=23$ vs. group 2: $<60$ minutes, $\mathrm{n}=17$ ) (Figure 1).

All patients gave their written informed consent and the study was approved by the local ethics committee (EK 373092013).

\section{PMVR}

The details of the procedure have been described previously ${ }^{6,8}$. In short, patients either were sedated or received general anaesthesia.

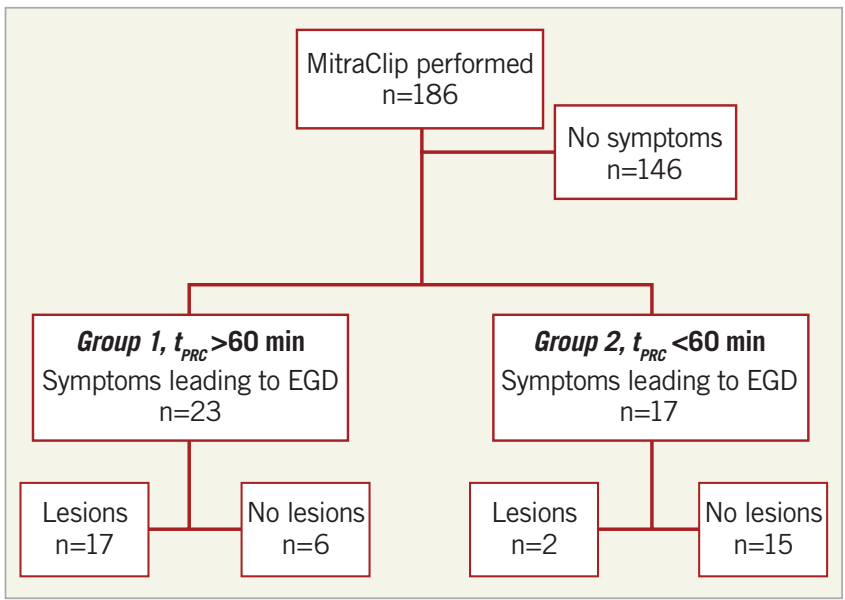

Figure 1. Patient selection. EGD: oesophago-gastro-duodenoscopy; $t_{P R C}$ : procedural time

The MitraClip (MC) delivery system was advanced to the right atrium under fluoroscopic guidance. Puncture of the interatrial septum, placement of the guidewire and placement of the clips were aided by fluoroscopy and TEE. TEE was performed by an experienced cardiologist in $2 \mathrm{D}$ and $3 \mathrm{D}$, using $\mathrm{iE} 33$ ultrasound machines equipped with X7-2t matrix array transducers (Philips Medical Systems, Andover, MA, USA). Protective shields for the probe were not used.

After clip placement, patients were monitored for at least 24 hours. EGD was performed depending on symptoms suggesting gastrointestinal origin, e.g., odynophagia, reflux, thoracic pain or hoarseness.

\section{STATISTICAL ANALYSIS}

Using logistic regression, we calculated the predicted probability of a lesion occurring, depending on procedural time. The chi-square test was used to calculate statistical significance. The omnibus test was used to calculate the significance of the coefficients in the model. Nagelkerke's $\mathrm{R}^{2}$ was used to describe the strength of association of the model while the Hosmer-Lemeshow test was used to assess the goodness of fit of the data to the model. The receiver operating characteristic (ROC) curve was created calculating the sensitivity and specificity of the probability of a lesion occurring as derived from the model of logistic regression and the procedural time elapsed. The significance of all other continuous parameters was calculated by the Student's t-test. Significance was assumed with $\mathrm{p}<0.05$, using the two-tailed Student's t-test, and $\mathrm{p}<0.01$ using logistic regression and the chi-square test. Standard error of the mean $(\mathrm{SEM} \pm$ ) or standard deviation ( $\mathrm{SD} \pm$ ) is shown, where appropriate. Statistical analysis was performed with SPSS, Version 20.0 (IBM Corp., Armonk, NY, USA).

\section{Results \\ CHARACTERISTICS}

Of 186 patients treated with PMVR, 40 were examined with EGD (Figure 1, Table 1). Symptoms developed within 48 hours after the 
Table 1. Symptoms leading to EGD.

\begin{tabular}{|l|r|r|c|}
\hline & $\begin{array}{c}\text { Group 1 } \\
(\mathbf{n = 2 3 )}\end{array}$ & $\begin{array}{c}\text { Group 2 } \\
(\mathbf{n = 1 7 )}\end{array}$ & p-value \\
\hline Odynophagia & $15(65.2 \%)$ & $11(64.7 \%)$ & 0.559 \\
\hline Reflux & $7(30.4 \%)$ & $6(35.3 \%)$ & 0.470 \\
\hline Thoracic pain & $4(17.4 \%)$ & $5(29.4 \%)$ & 0.388 \\
\hline Hoarseness & $3(13.0 \%)$ & $3(17.6 \%)$ & 0.344 \\
\hline
\end{tabular}

procedure and EGD was performed within 24 hours after symptom onset. There was no difference in symptoms between the groups. Also, demographic baseline characteristics did not differ (Table 2).

\section{PROCEDURE}

There were significantly more patients receiving multiple clips in group 1 (2.35 clips [SEM \pm 0.119 ] vs. 1.47 clips [SEM \pm 0.125$]$, $\mathrm{p}<0.0001$ ) (Table 3 ). The mean procedure time of all patients was 73 minutes [SEM $\pm 6.0 \mathrm{~min}$ ], with a median of 67 minutes [SEM \pm 6 , range of $20 \mathrm{~min}$ to $184 \mathrm{~min}$ ). Group 1 showed a significantly higher mean procedure time (97 minutes $[\mathrm{SEM} \pm 7 \mathrm{~min}$; $\mathrm{n}=23$ ] vs. 41 minutes [SEM \pm 3 min; $\mathrm{n}=17$ ]; $\mathrm{p}<0.0001$ ).

\section{OESOPHAGEAL LESIONS (OL)}

More OL were found in group 1 (17 [73.9\%] vs. 2 [11.8\%]; $\mathrm{p}<0,0001$ ) (Figure 2A, Table 4). The lesions found were haematoma and/or ulcerations, situated from mid oesophagus to the gastric level (Table 4, Figure 3). Proton pump inhibitors, i.e., pantoprazole $40 \mathrm{mg}$ bid, were sufficient to treat most lesions. In one patient in group 1, multiple ulcers, Forrest IIa and Ia, located at the distal end of the oesophagus and gastric cardia, had to be clipped to stop the bleeding (Figure 3C, Figure 3D). None of the patients required blood transfusions. There was no difference in symptoms or previous PPI therapy when comparing patients with OL to those without lesions (Table 5).

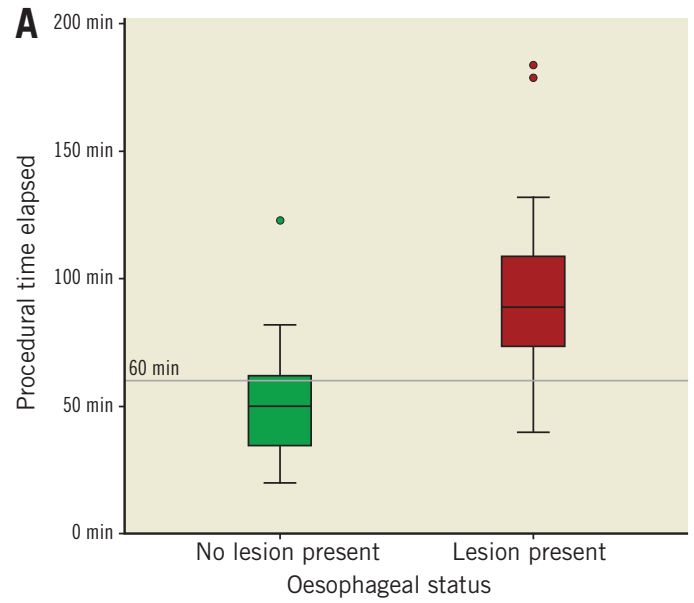

Table 2. Baseline characteristics.

\begin{tabular}{|c|c|c|c|}
\hline & Group $1(n=23)$ & Group $2(n=17)$ & $p$-value \\
\hline Mean age & $76.87[S D \pm 7.50]$ & $79.06[S D \pm 7.09]$ & 0.285 \\
\hline Male & 16 & 10 & \multirow{2}{*}{0.494} \\
\hline Female & 7 & 7 & \\
\hline CAD & $15(65.2 \%)$ & $8(47.1 \%)$ & 0.349 \\
\hline Patients with $\mathrm{MI}$ & $10(43.5 \%)$ & $5(29.4 \%)$ & 0.822 \\
\hline Functional MR & $12(52.2 \%)$ & $5(29.4 \%)$ & 0.158 \\
\hline Secondary MR & $11(47.8 \%)$ & $12(70.6 \%)$ & 0.158 \\
\hline ICM & $8(34.8 \%)$ & $5(29.4 \%)$ & 0.728 \\
\hline DCM & $3(13.0 \%)$ & $7(41.2 \%)$ & 0.059 \\
\hline AFib/AFlu & $21(43.5 \%)$ & $12(58.8 \%)$ & 0.350 \\
\hline DM 2 & 7 (56.5\%) & $9(58.8 \%)$ & 0.888 \\
\hline HLP & $13(56.5 \%)$ & $12(64.7 \%)$ & 0.612 \\
\hline PAD & $5(21.7 \%)$ & $7(41.2 \%)$ & 0.194 \\
\hline aHT & $14(56.5 \%)$ & $12(70.6 \%)$ & 0.377 \\
\hline OPD & $8(34.8 \%)$ & $3(17.6 \%)$ & 0.241 \\
\hline CKD & $17(73.9 \%)$ & $11(52.9 \%)$ & 0.178 \\
\hline PPI & $7(30.4 \%)$ & $6(35.3 \%)$ & 0.755 \\
\hline \multicolumn{4}{|c|}{$\begin{array}{l}\text { AFib/AFlu: atrial fibrillation/atrial flutter; aHT: arterial hypertension; } \\
\text { CAD: coronary artery disease; CKD: chronic kidney disease; } \\
\text { DCM: dilative cardiomyopathy; DM 2: type } 2 \text { diabetes mellitus; } \\
\text { HLP: hyperlipoproteinaemia; ICM: ischaemic cardiomyopathy; } \\
\text { MI: myocardial infarction; MR: mitral regurgitation; OPD: obstructive } \\
\text { pulmonary disease; PAD: peripheral artery disease; PPI: therapy with } \\
\text { a proton pump inhibitor }\end{array}$} \\
\hline
\end{tabular}

We observed no differences in laboratory results between groups before the procedure (Table 6). One day after, the leucocyte count in group 1 was slightly higher, without statistical significance. However, the change in the leucocyte count $(\triangle \mathrm{LEU})$ showed a significant statistical difference $(+2.00 \mathrm{Gpt} / \mathrm{L}[\mathrm{SEM} \pm 0.48]$ vs. $+0.54 \mathrm{Gpt} / \mathrm{L}[\mathrm{SEM} \pm 0.36], \mathrm{p}=0.028)$. When comparing patients with OL with patients without, respectively, $\triangle \mathrm{LEU}$ differed even more

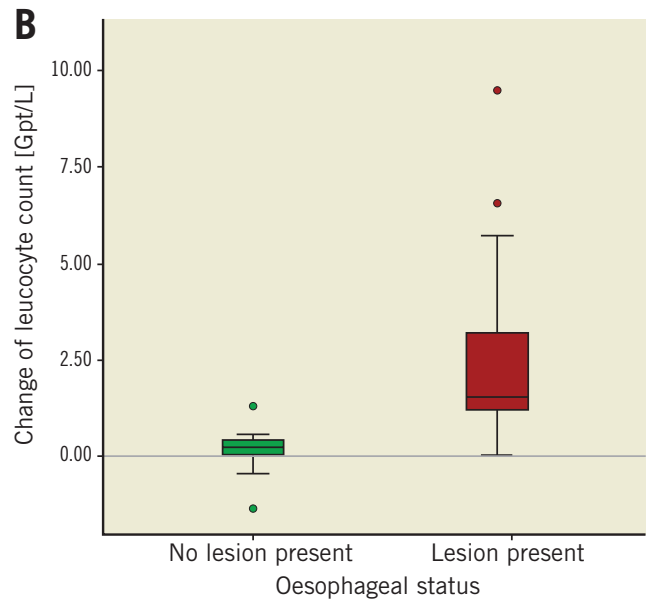

Figure 2. Oesophageal lesions depending on procedural time and change in leucocyte count. A) A longer procedural time is associated with the occurrence of an $O L(p<0.001$. Reference line at 60 minutes, dividing groups 1 and 2). B) Higher change in leucocyte count after the procedure is associated with the occurrence of an $\mathrm{OL}(p<0.001$. Reference line at $\Delta$ leucocyte count $0.00 \mathrm{Gpt} / \mathrm{L})$. 
Table 3. Procedure-related data.

\begin{tabular}{|c|c|c|c|}
\hline & Group $1(n=23)$ & Group $2(n=17)$ & $p$-value \\
\hline Clips implanted & $2.35[\mathrm{SEM} \pm 0.12]$ & $1.47[S E M \pm 0.13]$ & $<0.0001$ \\
\hline$t_{\mathrm{PRC}}$ & $97[$ SEM \pm 6.90$]$ & $44[S E M \pm 3.00]$ & $<0.0001$ \\
\hline$t_{\text {HOA }}$ & $12.5[\mathrm{SEM} \pm 1.75]$ & $13.5[\mathrm{SEM} \pm 2.53]$ & 0.752 \\
\hline$t_{H P I}$ & $8.0[S E M \pm 1.15]$ & $9.0[\mathrm{SEM} \pm 1.88]$ & 0.597 \\
\hline
\end{tabular}

Table 4. Oesophageal lesions observed.

\begin{tabular}{|l|c|c|c|}
\hline & $\begin{array}{c}\text { Group 1 } \\
(\mathbf{n = 2 3 )}\end{array}$ & $\begin{array}{c}\text { Group 2 } \\
(\mathbf{n = 1 7 )}\end{array}$ & $\boldsymbol{p}$-value \\
\hline Oesophageal lesions & $17(73.9 \%)$ & $2(11.8 \%)$ & $<0.0001$ \\
\hline Ulcer & $10(58.8 \%)$ & $2(100.0 \%)$ & \\
\hline Haematoma & $7(41.2 \%)$ & $0(0.0 \%)$ & \\
\hline \multicolumn{4}{|l|}{$\begin{array}{l}\text { Percentages of ulcer and haematoma expressed are relative to the } \\
\text { oesophageal lesions of the corresponding group. }\end{array}$} \\
\hline
\end{tabular}

$(+2.65 \mathrm{Gpt} / \mathrm{L}[\mathrm{SEM} \pm 0.56]$ vs. $+0.23 \mathrm{Gpt} / \mathrm{L}[\mathrm{SEM} \pm 0.12], \mathrm{p}<0.0001)$ (Figure 2B, Table 5). In this comparison, the post-interventional absolute leucocyte count was also significantly greater in those with an OL (10.11 Gpt/L [SEM \pm 0.67$]$ vs. $7.82 \mathrm{Gpt} / \mathrm{L}$ [SEM \pm 0.32$]$, $\mathrm{p}=0.003$ ). The rise in leucocytes was driven by a rise in neutrophils.

Neither the overall time patients spent in hospital $\left(\mathrm{t}_{\mathrm{HOA}}\right)$ nor the time spent in hospital after the MC procedure $\left(\mathrm{t}_{\mathrm{HPI}}\right)$ was different in the two groups (Table 3), or when comparing the patients with an OL with those who did not have such a lesion (Table 5).

We hypothesised that the procedural time elapsed $\left(\mathrm{t}_{\mathrm{PRC}}\right)$ is correlated to the formation of an OL. The logistic regression of $t_{P R C}$ showed a high significance $(\mathrm{p}<0.0001)$, with a good strength of association (Nagelkerke's $\mathrm{R}^{2}=0.468$ ) and acceptable fit of the data to the model (Hosmer-Lemeshow test, $\mathrm{p}=0.685$ ). The calculated odds ratio for

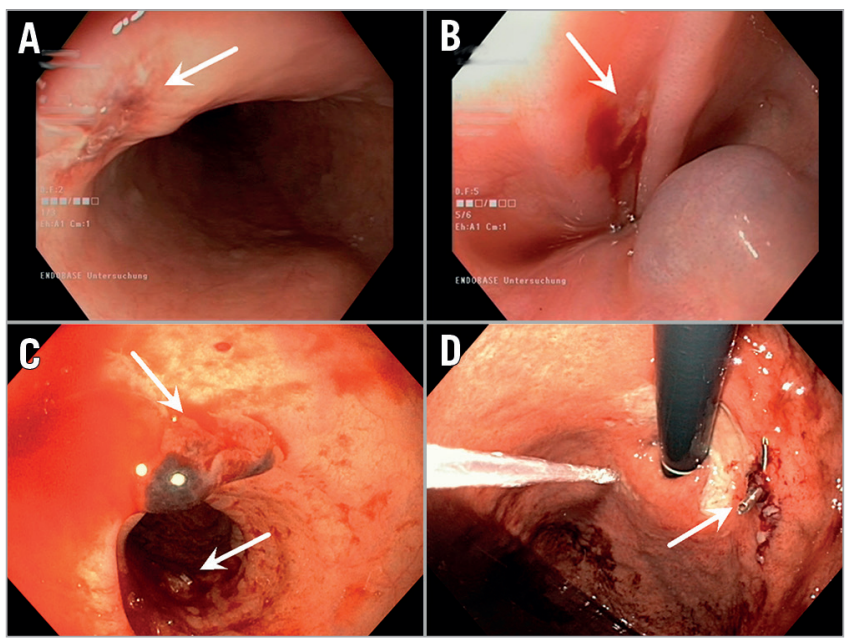

Figure 3. Different oesophageal lesions. A) Haematoma and laceration. B) Small ulcer. C) Haematoma and ulcer. D) Cardiac ulcer, clipped.
Table 5. Selected variables dependent on presence of oesophageal lesion.

\begin{tabular}{|c|c|c|c|c|}
\hline & $\begin{array}{l}\text { Lesion present } \\
\qquad(n=19)\end{array}$ & $\begin{array}{l}\text { No lesion present } \\
\quad(n=21)\end{array}$ & $p$-value \\
\hline \multicolumn{2}{|c|}{ pre-PPI therapy } & 7 [SEM \pm 0.114$]$ & $6[S E M \pm 0.101]$ & 0.588 \\
\hline \multicolumn{2}{|c|}{ Odynophagia } & $12[S E M \pm 0.114]$ & 14 [SEM \pm 0.105$]$ & 0.822 \\
\hline \multicolumn{2}{|c|}{ Reflux } & 6 [SEM \pm 0.110$]$ & 7 [SEM \pm 0.105$]$ & 0.909 \\
\hline \multicolumn{2}{|c|}{ Thoracic pain } & $4[S E M \pm 0.096]$ & $5[S E M \pm 0.095]$ & 0.840 \\
\hline \multicolumn{2}{|c|}{ Hoarseness } & $4[\mathrm{SEM} \pm 0.096]$ & $2[\mathrm{SEM} \pm 0.066]$ & 0.320 \\
\hline \multicolumn{2}{|l|}{$t_{\text {HОА }}$} & $14.47[S E M \pm 2.434]$ & 11.52 [SEM \pm 1.684$]$ & 0.326 \\
\hline \multicolumn{2}{|l|}{$t_{\text {HPI }}$} & $10.11[S E M \pm 0.0]$ & $7[\mathrm{SEM} \pm 0.884]$ & 0.149 \\
\hline \multirow[t]{3}{*}{ LEU } & pre & $7.45[S E M \pm 0.38]$ & $7.59[\mathrm{SEM} \pm 0.33]$ & 0.784 \\
\hline & post & $10.11[S E M \pm 0.67]$ & $7.82[\mathrm{SEM} \pm 0.33]$ & 0.003 \\
\hline & $\Delta$ & $+2.65[\mathrm{SEM} \pm 0.56]$ & $+0.23[\mathrm{SEM} \pm 0.12]$ & $<0.0001$ \\
\hline
\end{tabular}

$\Delta$ : mean change. LEU: leucocyte count; post: value after intervention; PPI: proton pump inhibitor; pre: value before intervention; $t_{\text {ноА }}$ : overall time spent in hospital; $t_{\text {нрі }}$ time spent in hospital after intervention

the time elapsed was 1.056 (CI: 1.020 to $1.114, \mathrm{p}=0.002$ ), showing that every minute elapsed increases the probability of the formation of an OL (Figure 4A). The ROC showed a good test performance of the calculated predicted probability of a lesion occurring and $t_{\mathrm{PRC}}$ (area under the curve 0.865, $\mathrm{p}<0.001$ ) (Figure 4B). At 67 minutes, we found a high specificity and sensitivity of 0.80 for an OL occurring. Calculating a more practical time frame for the occurrence of an OL, we found a corresponding range of $t_{\text {PRC }}$ from 62 to 72 minutes (sensitivity and specificity of 0.85 , respectively) (Figure 4A).

\section{Discussion \\ OVERVIEW}

Percutaneous edge-to-edge mitral valve repair is a safe procedure in a high-risk population ${ }^{4}$. While serious complications directly related to the procedure are rare, the role and risks of TEE during the procedure have not yet been addressed.

\section{TEE}

Considered a safe procedure, TEE is especially valuable in aiding cardiac surgery or interventions, such as atrial fibrillation ablation $^{16-19}$. While general discomfort during and after the procedure is common, serious complications are as rare as $0.18 \%{ }^{18,20}$. Most complications can be handled easily and mortality is low, i.e., less than $0.01 \%{ }^{20,21}$.

There are four possible ways in which the oesophagus can be injured during TEE. First, during placement of the probe, forceful manipulation can damage the mucosa ${ }^{16}$. In this case, besides damage to the oropharynx, one would expect the damage to be at the proximal end of the oesophagus ${ }^{16}$. In our study, the lesions were situated at mid oesophagus to gastric level, making injury by malpositioning unlikely. Secondly, damage to the oesophageal wall could be directly caused by pressure generated through flexion of the probe by the operator ${ }^{14,16}$, with pressure levels achieved as high as $8 \mathrm{kPa}^{13}$. Thirdly, sandwich compression of the oesophageal 
Table 6. Laboratory results.

\begin{tabular}{|c|c|c|c|c|}
\hline & Group $1(n=23)$ & Group 2 ( $n=17)$ & $p$-value \\
\hline \multirow{3}{*}{$\begin{array}{l}\text { LEU } \\
\text { (Gpt/L) }\end{array}$} & pre & 7.35 [SEM \pm 0.32$]$ & $7.76[S E M \pm 0.39]$ & 0.415 \\
\hline & post & 9.35 [SEM \pm 0.59$]$ & $8.30[S E M \pm 0.48]$ & 0.199 \\
\hline & $\Delta$ & $+2.00[\mathrm{SEM} \pm 0.48]$ & $+0.54[S E M \pm 0.36]$ & 0.028 \\
\hline \multirow{3}{*}{$\begin{array}{l}\mathrm{Hb} \\
(\mathrm{mmol} / \mathrm{L})\end{array}$} & pre & 7.29 [SEM \pm 0.21$]$ & $7.30[S E M \pm 0.31]$ & 0.981 \\
\hline & post & $6.47[S E M \pm 0.24]$ & $6.40[S E M \pm 0.21]$ & 0.832 \\
\hline & $\Delta$ & $-0.82[S E M \pm 0.18]$ & $-0.90[$ SEM \pm 0.17$]$ & 0.763 \\
\hline \multirow{3}{*}{$\begin{array}{l}\text { PLT } \\
\text { (Gpt/L) }\end{array}$} & pre & $203.00[$ [SEM \pm 13.31$]$ & 207.12 [SEM \pm 15.97$]$ & 0.843 \\
\hline & post & $174.52[S E M \pm 10.20]$ & $174.12[S E M \pm 11.62]$ & 0.979 \\
\hline & $\Delta$ & $-28.48[\mathrm{SEM} \pm 6.92]$ & $-33.00[\mathrm{SEM} \pm 0.38]$ & 0.650 \\
\hline \multirow{3}{*}{$\begin{array}{l}\text { Crea } \\
(\mu \mathrm{mol} / \mathrm{L})\end{array}$} & pre & $154.40[S E M \pm 18.89]$ & $131.18[$ [SEM \pm 9.54$]$ & 0.330 \\
\hline & post & $116.13[S E M \pm 9.28]$ & 111.94 [SEM \pm 11.02$]$ & 0.772 \\
\hline & $\Delta$ & $-38.27[\mathrm{SEM} \pm 10.79]$ & -19.24 [SEM \pm 6.05$]$ & 0.170 \\
\hline \multirow{3}{*}{$\begin{array}{l}\text { GFR } \\
(\mathrm{ml} / \mathrm{min})\end{array}$} & pre & $42.57[$ SEM \pm 4.11$]$ & 43.41 [SEM \pm 2.83$]$ & 0.876 \\
\hline & post & 53.96 [SEM \pm 4.32$]$ & $53.94[\mathrm{SEM} \pm 3.57]$ & 0.998 \\
\hline & $\Delta$ & $+11.39[\mathrm{SEM} \pm 2.04]$ & $+10.53[\mathrm{SEM} \pm 3.20]$ & 0.814 \\
\hline \multirow{3}{*}{$\begin{array}{l}\text { CrP } \\
\text { (mg/L) }\end{array}$} & pre & $14.81[\mathrm{SEM} \pm 4.42]$ & $15.95[\mathrm{SEM} \pm 4.25]$ & 0.858 \\
\hline & post & $28.94[\mathrm{SEM} \pm 4.23]$ & $29.66[\mathrm{SEM} \pm 5.89]$ & 0.920 \\
\hline & $\Delta$ & $+14.13[\mathrm{SEM} \pm 3.21]$ & +13.71 [SEM \pm 4.49$]$ & 0.938 \\
\hline
\end{tabular}

$\triangle$ : mean change. Crea: creatinine; CrP: C-reactive protein; GFR: glomerular filtration rate; $\mathrm{Hb}$ : haemoglobin; LEU: leucocyte count; PLT: platelet count; post: value after intervention; pre: value before intervention

wall by the TEE probe and the tissues surrounding the oesophagus, such as the aorta, the heart, or the trachea, could also result in pressure-related damage to the oesophagus and the tissues described. While case reports of damage to the spleen or recurrent laryngeal nerve palsy have been described ${ }^{22-24}$, one would generally expect relevant enlargement, displacement or deformities of the tissues mentioned to cause such damage. In the patients of this study, none of these alterations, except for the pronounced enlargement of the atria, typical for severe MR, was observed. This atrial enlargement could be one possible cause for the higher rate of lesions observed, when compared to a large study of 1,110 patients undergoing atrial fibrillation ablation, in which only three events of oesophageal haematoma, making up $0.27 \%$ of the study population, were attributed to TEE use during ablation. Due to the lack of definitive data, this association remains speculative. However, in the study mentioned, diagnosis was primarily made by $\mathrm{CT}$ and only then confirmed by EGD ${ }^{25}$. Therefore, underdiagnosis of oesophageal damage cannot be excluded, as CT might miss smaller lesions. Finally, thermal injury to the oesophagus is another plausible cause of damage to the oesophageal wall during TEE. Of the power needed to generate the images, $75 \%$ is converted into heat ${ }^{26}$. The probes can reach temperatures of $40.0^{\circ} \mathrm{C}$ and above while active. For instance, it has been shown that high temperature in the oesophagus during ablation of left atrial arrhythmias can cause thermal oesophageal damage in the form of ulcerations ${ }^{27}$. In our study, temperature in the oesophagus was registered through the TEE probes used. At temperatures above $40.0^{\circ} \mathrm{C}$, shutdown of the probe was initiated by the TEE machine.

\section{LEUCOCYTE COUNT}

We found a significant change of leucocyte count in our patients with OL. This finding is consistent with previous observations with leucocytosis as a marker of non-infective causes of inflammation ${ }^{28,29}$. In patients with upper gastrointestinal bleeding, increased leucocytosis is common and reflective of the severity of the bleeding episode ${ }^{30}$.

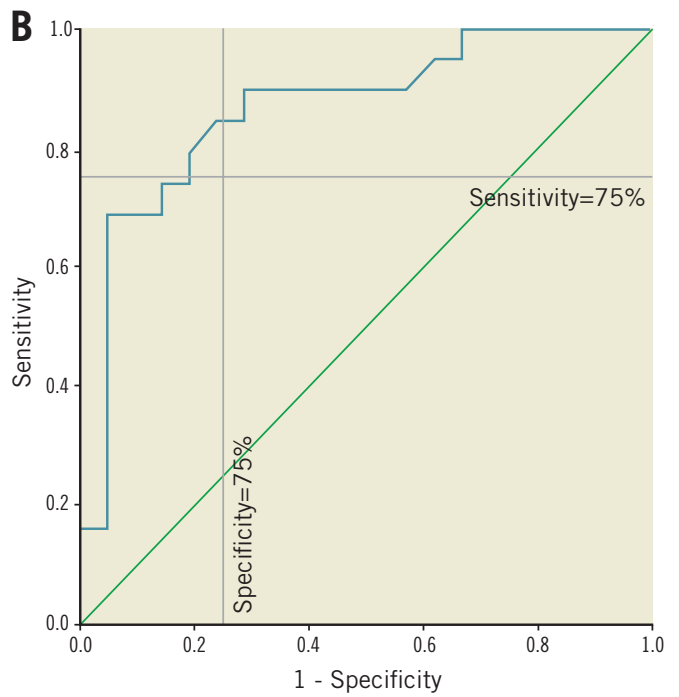

Figure 4. ROC curve and model of logistic regression. A) Model of regression, showing that, with each minute passed, the likelihood of an $O L$ occurring increases. Dotted reference line at 67 minutes $=80 \%$ specificity and sensitivity, each; continuous lines $=85 \%$ sensitivity (left, 62 min; specificity 75\%) and 85\% specificity (right, 72 min; sensitivity 75\%). B) Receiver operating characteristic curve (ROC curve) using elapsed procedural time to predict the probability of an OL occurring (area under the curve of $0.865 \mathrm{u2}$; horizontal reference line at sensitivity of $75 \%$; vertical reference line at $75 \%$ specificity). 
Although the mechanisms leading to the OL observed are ambiguous, a longer contact time of an active TEE probe to the oesophageal wall, causing thermal damage, and shear stress and/ or friction caused by prolonged flexion of the probe seem the most likely causes leading to damage of the oesophageal tissue.

\section{Study limitations}

Although we present data from a prospective registry, as EGD was performed at the physician's discretion, a selection bias cannot be excluded. Such errors might be aggravated by the low number of individuals included in the study. As this study was held at one centre only, the external validity might be biased. For instance, differences in personnel and logistics in general and the experience of the TEE operator in particular may have caused variations in the outcome. However, there were only a limited number of highly qualified TEE operators, following the same protocol during the procedure.

When compared to the number of patients undergoing EGD because of gastrointestinal symptoms (40 over 186; $21.5 \%$ ), only 19 patients presented with actual OL. This raises the question as to the origin of symptoms in the remaining 21 patients. There are multiple explanations: the local anaesthetic used during TEE can create discomfort, while the TEE may irritate the oesophagus without causing visible damage. Also, patients under general anaesthesia during the procedure may experience malaise caused by orotracheal intubation. Interpretation is intricate as patients cannot distinguish between symptoms arising from harmless or harmful origins.

Our interpretation of the findings is that a longer procedure leads to oesophageal damage due to pressure by prolonged placement of the TEE probe and due to heat by longer imaging time. The procedure time recorded is not equal to TEE imaging time during the procedure, but shorter, as TEE placement is carried out shortly before the procedure begins. Nevertheless, both the procedure time and the TEE imaging time are closely connected, with a longer procedure time relating to a longer TEE imaging time. Ideally, one would need a device that exactly measures the time in which the TEE probe is active and the time the probe is on standby. However, so far, echocardiography machines are not programmed to record this or the temperature development or the mean temperature reached, but only the present temperature by the non-calibrated probe. One might argue that the actual temperature in the oesophagus would be better measured with a calibrated temperature probe. However, the extra probe would not only cause more pressure by itself but most likely lead to a more difficult operation of the TEE probe, hence increasing the need for more flexion of the probe for better image quality and prolonging the operation, thus increasing pressure and temperature, promoting further damage to the oesophageal wall.

In this study, we only investigated the baseline laboratory results and their dynamic to the day after the procedure. While a longer timeframe might have shown more changes, the significant rise of leucocytes shown in this setting shows the importance of early laboratory controls.
As some patients were already receiving PPI before PMVR, a bias based on pre-treatment cannot be ruled out. However, the preoperative prevalence of PPI treatment was similar in both groups and in those with a lesion compared to those without. Patients with OL were sufficiently treated with PPI in most of the cases. This raises the question as to whether PPI, when administered routinely before PMVR, could prevent the formation of OL. This must be addressed in a different and adequately powered study.

With the data of this study, one might theorise that OL caused by TEE during PMVR only marginally affects the post-procedural outcome, as no blood transfusions were necessary, most of the patients only needed PPI and the time patients spent in hospital was not prolonged. Yet, one must keep in mind that the small sample size again might cause a bias, leading to a false sense of security.

As mentioned above, EGD was only performed when suspicion was raised by symptoms implicating the gastrointestinal tract. Given the relation of the time elapsed to the occurrence of OL, one might speculate that damage to the oesophagus caused by TEE during the procedure is underdiagnosed. On the other hand, no EGD was performed directly before the procedure. Therefore, unrelated pre-existing OL may have been mistaken for new ones, caused by the TEE.

The degree of flexion of the probe cannot be measured, leaving the actual damage caused by TEE movement unclear. However, early studies made on TEE suggest that even high flexion of the probe rarely causes enough pressure to cause relevant damage to the oesophagus ${ }^{13}$. Hence, damage to the oesophagus by high temperature might be more likely.

\section{Conclusions}

Oesophageal damage by TEE should be appreciated as a possible adverse effect after PMVR, carrying the risk of pain and chest discomfort. Relevant bleeds or even oesophageal perforation may increase morbidity and mortality. An exceptional rise of leucocyte count could be a clue to help in identifying those patients at highest risk after PMVR. Larger controlled prospective trials should be undertaken to elucidate further the danger of oesophageal damage by TEE during PMVR.

\section{Impact on daily practice}

Prolonged use of TEE during PMVR increases the risk of oesophageal damage. An exceptional rise of leucocyte count after PMVR may herald this damage.

\section{Conflict of interest statement}

The authors have no conflicts of interest to declare.

\section{References}

1. Triantafyllis AS, Kortlandt F, Bakker AL, Swaans MJ, Eefting FD, van der Heyden JA, Post MC, Rensing BW. Long-term survival and preprocedural predictors of mortality in high surgical 
risk patients undergoing percutaneous mitral valve repair. Catheter Cardiovasc Interv. 2016;87:467-75.

2. Giannini C, Fiorelli F, De Carlo M, Guarracino F, Faggioni M, Giordano P, Spontoni P, Pieroni A, Petronio AS. Comparison of Percutaneous Mitral Valve Repair Versus Conservative Treatment in Severe Functional Mitral Regurgitation. Am J Cardiol. 2016; 117:271-7.

3. D'Ascenzo F, Moretti C, Marra WG, Montefusco A, Omede P, Taha S, Castagno D, Gaemperli O, Taramasso M, Frea S, Pidello S, Rudolph V, Franzen O, Braun D, Giannini C, Ince H, Perl L, Zoccai G, Marra S, D'Amico M, Maisano F, Rinaldi M, Gaita F. Meta-analysis of the usefulness of Mitraclip in patients with functional mitral regurgitation. Am J Cardiol. 2015;116:325-31.

4. Munkholm-Larsen S, Wan B, Tian DH, Kearney K, Rahnavardi M, Dixen U, Kober L, Alfieri O, Yan TD. A systematic review on the safety and efficacy of percutaneous edge-to-edge mitral valve repair with the MitraClip system for high surgical risk candidates. Heart. 2014;100:473-8.

5. Rana BS, Calvert PA, Punjabi PP, Hildick-Smith D. Role of percutaneous mitral valve repair in the contemporary management of mitral regurgitation. Heart. 2015;101:1531-9.

6. Deuschl F, Schofer N, Lubos E, Blankenberg S, Schäfer U. Critical evaluation of the MitraClip system in the management of mitral regurgitation. Vasc Health Risk Manag. 2016;12:1-8.

7. Schau T, Isotani A, Neuss M, Schopp M, Seifert M, Hopfner C, Burkhoff D, Butter C. Long-term survival after MitraClip( $\left({ }^{\circledR}\right)$ therapy in patients with severe mitral regurgitation and severe congestive heart failure: A comparison among survivals predicted by heart failure models. J Cardiol. 2016;67:287-94.

8. Lesevic H, Sonne C, Braun D, Orban M, Pache J, Kastrati A, Schomig A, Mehilli J, Barthel P, Ott I, Sack G, Massberg S, Hausleiter J. Acute and Midterm Outcome After MitraClip Therapy in Patients With Severe Mitral Regurgitation and Left Ventricular Dysfunction. Am J Cardiol. 2015;116:749-56.

9. Nickenig G, Estevez-Loureiro R, Franzen O, Tamburino C, Vanderheyden M, Luscher TF, Moat N, Price S, Dall'Ara G, Winter R, Corti R, Grasso C, Snow TM, Jeger R, Blankenberg S, Settergren M, Tiroch K, Balzer J, Petronio AS, Büttner HJ, Ettori F, Sievert H, Fiorino MG, Claeys M, Ussia GP, Baumgartner H, Scandura S, Alamgir F, Keshavarzi F, Colombo A, Maisano F, Ebelt H, Aruta P, Lubos E, Plicht B, Schueler R, Pighi M, Di Mario C; Transcatheter Valve Treatment Sentinel Registry Investigators of the EURObservational Research Programme of the European Society of Cardiology. Percutaneous mitral valve edgeto-edge repair: in-hospital results and 1-year follow-up of 628 patients of the 2011-2012 Pilot European Sentinel Registry. J Am Coll Cardiol. 2014;64:875-84.

10. Feldman T, Kar S, Rinaldi M, Fail P, Hermiller J, Smalling R, Whitlow PL, Gray W, Low R, Herrmann HC, Lim S, Foster E, Glower D; EVEREST Investigators. Percutaneous mitral repair with the MitraClip system: safety and midterm durability in the initial EVEREST (Endovascular Valve Edge-to-Edge REpair Study) cohort. J Am Coll Cardiol. 2009;54:686-94.
11. Silvestry FE, Rodriguez LL, Herrmann HC, Rohatgi S, Weiss SJ, Stewart WJ, Homma S, Goyal N, Pulerwitz T, Zunamon A, Hamilton A, Merlino J, Martin R, Krabill K, Block PC, Whitlow P, Tuzcu EM, Kapadia S, Gray WA, Reisman M, Wasserman H, Schwartz A, Foster E, Feldman T, Wiegers SE. Echocardiographic guidance and assessment of percutaneous repair for mitral regurgitation with the Evalve MitraClip: lessons learned from EVEREST I. J Am Soc Echocardiogr. 2007;20:1131-40.

12. Siegel RJ, Luo H, Makar M, Beigel R. Optimal use of echocardiography in valvular heart disease evaluation. Heart. 2015; 101:977-86.

13. Urbanowicz JH, Kernoff RS, Oppenheim G, Parnagian E, Billingham ME, Popp RL. Transesophageal echocardiography and its potential for esophageal damage. Anesthesiology. 1990;72: 40-3.

14. Piercy M, McNicol L, Dinh DT, Story DA, Smith JA. Major complications related to the use of transesophageal echocardiography in cardiac surgery. J Cardiothorac Vasc Anesth. 2009;23: 62-5.

15. Maisano F, Franzen O, Baldus S, Schäfer U, Hausleiter J, Butter C, Ussia GP, Sievert H, Richardt G, Widder JD, Moccetti T, Schillinger W. Percutaneous mitral valve interventions in the real world: early and 1 -year results from the ACCESS-EU, a prospective, multicenter, nonrandomized postapproval study of the MitraClip therapy in Europe. J Am Coll Cardiol. 2013;62:1052-61.

16. Hilberath JN, Oakes DA, Shernan SK, Bulwer BE, D'Ambra MN, Eltzschig HK. Safety of transesophageal echocardiography. J Am Soc Echocardiogr. 2010;23:1115-27.

17. Min JK, Spencer KT, Furlong KT, DeCara JM, Sugeng L, Ward RP, Lang RM. Clinical features of complications from transesophageal echocardiography: a single-center case series of 10,000 consecutive examinations. J Am Soc Echocardiogr. 2005; 18: 925-9.

18. Shintani H, Nakano S, Matsuda H, Sakai K, Taniguchi K, Kawashima Y. Efficacy of transesophageal echocardiography as a perioperative monitor in patients undergoing cardiovascular surgery. Analysis of 149 consecutive studies. J Cardiovasc Surg (Torino). 1990;31:564-70.

19. Kumar S, Brown G, Sutherland F, Morgan J, Andrews D, Ling LH, McLELLAN AJ, Lee G, Robinson T, Heck P, Halloran K, Morton J, Kistler P, Kalman JM, Sparks PB. The transesophageal echo probe may contribute to esophageal injury after catheter ablation for paroxysmal atrial fibrillation under general anesthesia: a preliminary observation. J Cardiovasc Electrophysiol. 2015;26: 119-26.

20. Daniel WG, Erbel R, Kasper W, Visser CA, Engberding R, Sutherland GR, Grube E, Hanrath P, Maisch B, Dennig K, et al. Safety of transesophageal echocardiography. A multicenter survey of 10,419 examinations. Circulation. 1991;83:817-21.

21. Augoustides JG, Hosalkar HH, Milas BL, Acker M, Savino JS. Upper gastrointestinal injuries related to perioperative transesophageal echocardiography: index case, literature review, 
classification proposal, and call for a registry. $J$ Cardiothorac Vasc Anesth. 2006;20:379-84.

22. Sakai K, Nakamura K, Hosoda S. Transesophageal echocardiographic findings of papillary muscle rupture. Am J Cardiol. 1991;68:561-3.

23. Zwetsch G, Filipovic M, Skarvan K, Todorov A, Seeberger MD. Transient recurrent laryngeal nerve palsy after failed placement of a transesophageal echocardiographic probe in an anesthetized patient. Anesth Analg. 2001;92:1422-3.

24. Chow JL, Mariano ER, Liang D. Transesophageal echocardiography assessment of severe aortic regurgitation in type a aortic dissection caused by a prolapsed circumferential intimal flap. J Cardiothorac Vasc Anesth. 2007;21:85-7.

25. Kumar S, Ling LH, Halloran K, Morton JB, Spence SJ, Joseph S, Kistler PM, Sparks PB, Kalman JM. Esophageal hematoma after atrial fibrillation ablation: incidence, clinical features, and sequelae of esophageal injury of a different sort. Circ Arrhythm Electrophysiol. 2012;5:701-5.
26. Greene MA, Alexander JA, Knauf DG, Talbert J, Langham M, Kays D, Ledbetter D. Endoscopic evaluation of the esophagus in infants and children immediately following intraoperative use of transesophageal echocardiography. Chest. 1999;116: 1247-50

27. Halm U, Gaspar T, Zachäus M, Sack S, Arya A, Piorkowski C, Knigge I, Hindricks G, Husser D. Thermal esophageal lesions after radiofrequency catheter ablation of left atrial arrhythmias. Am J Gastroenterol. 2010;105:551-6.

28. Asadollahi K, Beeching NJ, Gill GV. Leukocytosis as a predictor for non-infective mortality and morbidity. QJM. 2010;103: 285-92.

29. Asadollahi K, Hastings IM, Beeching NJ, Gill GV, Asadollahi P. Leukocytosis as an alarming sign for mortality in patients hospitalized in general wards. Iran J Med Sci. 2011;36:45-9.

30. Chalasani N, Patel K, Clark WS, Wilcox CM. The prevalence and significance of leukocytosis in upper gastrointestinal bleeding. Am J Med Sci. 1998;315:233-6. 